\title{
SOME NOTES ON RELIGIOUS RADICALIZATION AND TERRORISM IN INDONESIA
}

\author{
Donny Syofyan \\ Faculty of Humanities, Andalas University \\ e-mail:donnysyofyan@fib.unand.ac.id \\ DOI: bttp:/ / dx.doi.org/10.30983/islam_realitas.v2i2.111
}

\begin{tabular}{|c|c|c|}
\hline Diterima: 2 Agustus 2016 & Direvisi : 19 September 2016 & Diterbitkan: 20 Desember 2016 \\
\hline
\end{tabular}

\begin{abstract}
Terrorism should not be a security issue in any part of the world anymore. It truly goes out of mainstream, namely intellectual and cultural dimensions. The dimensions are non security issues, critical education, religious depersonalization, the needs for ambassadors, reconciling liberal and fundamental Muslims and cyber religion. These dimensions constitute major aspects to be viewed when it comes to fathoming religious radicalization and terrorism across the country. Various terrorist attacks have taken place across Indonesia in the past few years. Different approaches ranging from security to cultural modes have been applied. Yet, expected outcome, which is peace, remains far from public hope. Rather than spending physical and financial resources, intellectual approach is seriously pressing. This article attempts to look into the very nature of religious radicalization leading to terrorist acts across the country
\end{abstract}

Keywords: Religious, Radicalism, Terorism

\section{Abstrak}

Terorisme semestinya tidak lagi menjadi masalah keamanan di belahan dunia manapun. Hal tersebut berada dalam sudut pandang di luar mainstrem, yaitu dimensi intelektual dan budaya. Dimensi-dimensi tersebut di antaranya; masalah non keamanan, pendidikan kritis, depersonalisasi agama, kebutuhan akan duta besar, mendamaikan umat Islam yang liberal dan fundamental dan fenomena agama maya. Dimensi-dimensi ini merupakan aspek pembuktian utama yang harus dilihat ketika ingin memahamani radikalisasi agama dan terorisme di seluruh negeri. Berbagai serangan teroris telah terjadi di seluruh Indonesia dalam beberapa tahun terakhir. Pendekatan yang berbeda mulai dari keamanan hingga budaya telah diterapkan, namun hasil yang diharapkan, yaitu perdamaian, masih jauh dari harapan masyarakat. Daripada menghabiskan sumber daya fisik dan keuangan, akan lebih baik menekankan pendekatan intelektual secara serius. Artikel ini mencoba untuk melihat dimensi intelektual dan kebudayaan dalam mencari solusi dari dampak negatif radikalisasi agama bertolak dari pengalaman catatan-catatan tentang terorisme dan radikalisme agama di Indonesia.

Kata Kunci: Agama, Radikalisme, Terorisme

\section{Background}

In the last two decades, Indonesia has experienced various terrorist attacks. A bomb explosion shook the pluralist republic. For example Bali I bombing, Bali II bombing, Australian Embassy bombing, Hotel JW Marriot I bombing, Hotel JW Marriot II bombing, Hotel Ritz Carlton bombing, "book bombing" addressed to a number of figures,
"Friday bombing" in Mapolres Cirebon mosque, and suicide bombing at Bethel Injil Sepenuh (GBIS) Kepunton Church, Solo. The post-reformation marked by the opening of democratic taps has become a fertile ground for the growth of radical Islamic groups. The phenomenon of radicalism among Muslims is often based on harsh religious ideology, 
intolerance and narrow religious understanding ${ }^{1}$.

Various terrorist attacks which have taken place across in some parts of Indonesia are concrete proof how the use of a militaristic security approach is not effective enough to counter the movement of terrorism and Islamic radicalism to its roots. Therefore, various approaches to the handling of terrorism and other Islamic radicalism must also always be pursued ${ }^{2}$.

In response to various terrorist attacks, government and the police had applied security approach. It is far less adequate, though, when it comes to uprooting the terror act involving bombers mostly consisting of young people. Radicals in Indonesia were getting younger, with some being arrested while in their teens. Farhan Mujahidin and Mukhsin Sanny Permadi, two Solo terrorists who were recently gunned down by police officers, were only 19 . $^{3}$

In general, two psychological approaches are often used to predict the root of acts of terrorism, namely 'syndrome approach' and 'instrumental approach'. ${ }^{4}$ Syndrome approach views acts of terrorism as a manifestation of a specific psychological construct that can be identified, such as specific personality type, social background, ideology, and so forth, whereas instrumental approach views acts of terrorism as a mean to achieve an objective. The second approach relies on a cognitive process called 'moral calculation' which is subjective for the individual, which tries to test whether a way or

${ }^{1}$ Rokhmad, Abu, "Radikalisme Islam dan Upaya Deradikalisasi Paham Radikal", Walisongo: Jurnal Penelitian Sosial Keagamaan, 20.1, 2012, h. 79-114.

2 Muqoyyidin, Andik Wahyun, "Membangun Kesadaran Inklusif Multikultural untuk Deradikalisasi Pendidikan Islam", Jurnal Pendidikan Islam, 2.1, 2013, p.131-151.

${ }^{3}$ The Jakarta Post, 13 September, 2012.

${ }^{4}$ Zora, A., Sukabdi, "Terrorism in Indonesia: A Review on Rehabilitation and Deradicalization" JTR, Vol. 6, Issue. 2, 2015, p. 36. method will reap more benefits than losses in order to achieve the desired outcome ${ }^{5}$. In relation with this, the phenomenon of focalism arises, namely an increase of subjective attention toward an objective by ignoring other objectives. For example, the desire of perpetrators of terrorism to free their nation from tyranny or defend their religion can defeat his attention to other desires, such as protecting the innocent or fostering religious harmony ${ }^{6}$. The perpetrators of these acts thought that only violence will be able to help them in achieving their objective and capturing the attention of parties which are the target of the attack as soon as possible.

Based on the background, this article will analyze the intellectual and cultural dimensions of finding solutions to the negative impact of religious radicalization from the experience of records on terrorism and religious radicalism in Indonesia. One of the efforts that will be offered in the last section is to address the critical education of radicalism

\section{Gafatar and Religious Depersonalization.}

The burning of Gafatar (Fajar Nusantara Movement) members' settlement at Mempawah regency, West Kalimantan has leaved tragedy to the nation. Any efforts to handle Gafatar group should not be based on security and isolating approaches. Since the charm of organization is associated with its personality cult, both individually and collectively, the need for religious depersonalization-an effort to deconstruct personality cult-based religious expressionneeds to be a collective movement. In so

${ }^{5}$ C Ummah, Sun, "Akar Radikalisme Islam di Indonesia", Humanika, 12.1, 2012, p. 12.

${ }^{6}$ Abbas, Afifi Fauzi, "Aspek Aspek Kemanusiaan Dalam Terorisme Berdasarkan Kajian Fikih", Islam Realitas: Journal of Islamic \& Social Studies, 2.1, 2016, p. 19 . 
doing, religious rationalism and original religiousness are central to deal with the issue ${ }^{7}$.

Many people have been attracted to Gafatar that actually tramples the divine messages due to loss of rationality in understanding and executing religious messages. Their decisions to leave family members, ignore their parents' advice, leave pray five times a day, for instance, conform to the loss of rationally religious expression. We do not know exactly their key teachings which, in turn, interest many people to join the organization. Yet, overlooking their own family and turning their back on their parents' advice is clearly contrary to the teachings of Islam and the doctrine of any other religions.

Religious Affairs Minister Lukman Hakim Saifuddin said ${ }^{8}$, on Wednesday that Gafatar was an illegal organization that must not be followed by community members. The group had the potential to promote radicalism. Furthermore, according to studies from the Indonesian Ulema Council (MUI), the ideology upheld by Gafatar was not in accordance with Islam, as the group combined elements of Islam, Christianity and Judaism into one teaching.

Rational diversity means that religious truth is not against common sense given its role to enforce and perfect the sacred texts. People could worship tree, snake or lightning without taking rational basis into account. The story of the Prophet Ibrahim seeking God is the most valid model of rational diversity. This story presents Abraham's critical attitude who always keep questioning due to his disillusion with the moon or the sun initially regarded as God. Critical attitude, characterized by the awareness to always ask and consistency to validate something with the Koran, becomes a

7 Saradin, Fauzi, "Strategi Penanggulangan Komunitas Gafatar dalam Rangka Mewujudkan Keamanan dalam Negeri yang Kondusif (Studi Kasus di Kabupaten Mempawah)", Jurnal Nestor Magister Hukum, 4.4, 2016, p. 24.

8 The Jakarta Post, 13 January, 2016 buffer for Muslims not to be victims of religious indoctrination of distorted understanding'.

Equally important, rational religiosity really requires a Muslim to not keep away from diverse sources of truth and learning. This is where the dialogue will be a fertile space and opportunity of brainwashing trend in conveying the messages of misinterpreted would erode. Dialogical approach cannot be ignored to maintain the ups and downs of faith following human beings' love for narrating. As homo narrativus (creature of narration), as stated by Walter Fisher, the need for telling story, sharing, debating, deliberating turn into a measure of human existence, including in the search for truth and happiness. Therefore, irrational religious indoctrination, as Gafatar takes, will not last as long as the adherents of Islam subscribe to inclusive religiousness, open their eyes and ears to any sources, not just one.

Along with religious rationality, original religiousness is also necessary to counteract the religious personalization. This approach is relatively different from the religious purification mainly focusing of eradicating takhayul (superstition), bid'ah (herecy) and churafat (myth). Rather it carries out religious messages in accordance with the Sunnah of the Prophet which is clearly seen in the history of the life of the Prophet (sirahnabawiyah). The Prophet's journey of life, as seen from his apostolic period, actually teaches Islamic tenets to the public must be alphabetic, no skipping or without consideration. The real secret behind such an alphabetical approach is closely bound to human psychology which tends to understand and carry out the commands of Allah and His Messenger gradually and slowly.

${ }_{9}$ Millie, Julian, and Linda Hindasah, "Regional Aspects of the Indonesian Ulama Council's Ideological Turn", The Asia Pacific Journal of Anthropology, 16.3, 2015, p.260-281. 
In the early days of his preaching in Mecca for 13 years, what the Prophet Muhammad did was not to build a mosque but strengthen the monotheistic faith of his Companions and Muslims. The problem of monotheism in the minds and hearts of the Muslims is vital because it is the foundation to build a solid understanding for a Muslim to carry out the commands of Allah, knowingly and willingly. Studying Islam that begins with the door of monotheism is very instrumental in establishing immunity on external pressure (wealth, fame, descendants) that may destabilize one's confidence on the one hand and internal tension (religious baseless doctrines) which shifts one's moderate into more radical religiousness on the other side ${ }^{10}$.

One who already adhered to one hundred percent monotheism will not be easily swayed by the pull of strong person's doctrines, especially those promising shortterm profits contrary to the majority of the religious notions. In the case of Gafatar, the personality cult has been dragged so far at the expense of ordinary people who actually have religiously moderate expression and do not have any ideological interests.

\section{In Search of Tolerance Ambassadors}

Papua Police have charged two people for allegedly inciting a riot in Tolikara district, which saw a mosque burn to the ground last week and triggered widespread fears of sectarian violence across the country. The police suspect that the two people, with the initials JW and AK, instigated the riot that resulted in the death of a teenager and the injury of 12 others of various ages. The National Intelligence Agency (BIN) chief Sutiyoso has reminded the police of possible security threats a couple of days prior to the

${ }^{10}$ Hendry, Eka, "Pengarus Utamaan Pendidikan Damai (Peaceful Education) dalam Pendidikan Agama Islam (Solusi Alternatif Upaya Deradikalisasi Pandangan Agama)", At-Turats, 9.1, 2015, p. 3-13. burning of the mosque. Despite the warning, the tragic event became unavoidable, suggesting that security-based anticipation is actually never efficacious in muddling through social, political and religious tensions ${ }^{11}$.

Recurring cycle of religious violence should alert the citizens of this country how this nation is asleep to collective amnesia: negligence for the tragedy that continues to occur. Frankly speaking, what makes us indifferent to the amnesia is the government's tendency to perceive religious conflict, be it latent or manifest, through the gaze of security. The security approach cannot be separated from the legally formal requirements necessary to uphold justice for the victims, namely Muslims in Tolikara tragedy. Yet cultural work would be much more productive to have religious tolerance and harmony established.

The effort may begin with the formation of tolerance ambassadors consisting of public figures known for their integrity and credibility, not for their controversy. They ought to be a mixture of local and national people. The local involvement is very crucial given their strong cultural legitimacy in their own community, while the national figures turn into spokespersons with their powerful networking ${ }^{12}$.

Thanks to the supports of government, religious organizations and the mass media, the ambassadors of tolerance need to apply cultural efforts which at least integrate three things at once;cross-cultural communication, indigenous peoples and local wisdom. Crosscultural communication is very helpful in

${ }^{11}$ Fealy, Greg, "Islamic Radicalism in Indonesia: the Faltering Revival?", Southeast Asian Affairs, 2004, p. 104-121.

12 Van Bruinessen, Martin, "Genealogies of Islamic Radicalism in Post-Suharto Indonesia", South East Asia Research, 10.2, 2002, p. 117-154. See also, Razi, Syafwan, "Dari Islam Radikal ke Islam Pluralis Genealogi Gerakan Paderi dan Pengaruhnya terhadap Islam Pluralis di Perbatasan Minangkabau", Masyarakat Indonesia, 41.1, 2016, h. 15-27. 
preventing prejudice and stereotype against particular people or culture. Reducing Papuans into primitive societies or belligerents, for example, rises from the absence of crosscultural understanding of the Papuans as adhering to the ethics of mutual brotherhood and sisterhood (kitorangbasudara). Through the cross-cultural communication, the seeds of religious misunderstanding and tensions can be minimized because one will view others from the perspective of the target culture instead of the eyes of foreign guests or outside observers.

The involvement of indigenous people becomes inevitable owing to the fact that they are the most crucial perpetrators of solidarity and harmony in the most dominant units of society in rural area and urban suburbs. The ambassadors of tolerance must visit and make heart-to-heart interaction with the indigenous people following their affective and psychomotor abilities. The two competences are the key to justifying people's readiness or refusal to live with diversity resting on the adage of cooperating in the agreed matter and being tolerant in terms of the dispute. Indigenous people, who have been perceived as the group of people easily misled by sensitive religious issues, are essentially those ready to stand for tolerance so long as respect for cultural identity is practically carried out ${ }^{13}$.

Equally important, tolerance will not run without taking local wisdom into account. Actually Papuans are noted for their tolerant behavior. Adherents of different religions such as Christians and Muslims have mutual respect and live for years. Conflicts arose when a number of radical priests harmful to religious harmony began to carry out their mission in Papua, especially in West Papua. In Manokwari (West Papua province), for

13 Sirozi, Muhammad, "The Intellectual Roots of Islamic Radicalism in Indonesia: Ja 'far Umar Thalib of Laskar Jihad (Jihad Fighters) and His Educational Background", The Muslim World, 95.1, 2005, p. 81-120. instance, people opposed to a great mosque and Asri housing complex. They thought that Papua must be protected to be a land of peace and Manokwari as a Gospel city.

Any attempts to mainstream local wisdom, both in Papua and in other areas of the archipelago, would be operational by esteeming local values and institutions in every decision-making and religious teaching, like the construction of worship places and religious propagation. Resistance to the spread of religion will recede when local wisdom cushions people's system of belief. This is the essence of religious indigenization.

The ambassadors of tolerance are not brand ambassadors or a beauty queen who move and work in accordance with financial sponsor or are related to the so called 'rating'. They are not only knowledgeable and transparent figures but also activists who devote their life to reviving the lost and scattered wisdom-tolerance, brotherhood and mutual cooperation. Their success is not determined by the popularity of their action but by their ability to work in quiet setting without public hustle and bustle and the exposure of the media.

\section{Reconciling Liberal and Fundamental Muslims}

The writer/was about to attend a discussion of a book written by Canadian activist Irshad Manji at Gadjah Mada University (UGM) in Yogyakarta on Wednesday in 2012. As widely predicted, the discussion organized by the Center for Religious and Cross-Cultural Studies (CRCS), was eventually canceled because of protests from campus-based Muslims students and HizbutTahrir Indonesia (HTI) ${ }^{14}$.

Much to my surprise, the writer found that the tension is not over yet. While Manji

14 Van Bruinessen, Martin, "Genealogies of Islamic radicalism in post-Suharto Indonesia.....", p. 117-154 
discussed her book Allah, Liberty and Love at the Institute for Islamic and Social Studies (LKiS) later in the day, dozens of Indonesian Mujahidin Council (MMI) members forcibly stopped the discussion. The invasion left five people injured and damaged the LKiS building.

Manji, a writer and award-winning liberal Muslim reform advocate, has made headlines as she was first rejected by the police, residents and Islam Defenders Front (FPI) to deliver a presentation and launch her latest book in South Jakarta. Compared to her previous visits to Indonesia over the past four years, public resistance to her now is very surprising ${ }^{15}$.

Many have been disappointed with the way the police handled the protests against the discussion. Some believe that any parties standing against Manji's view should debate in an open and healthy manner instead of menacing and offending her owing to her sexual orientation as a lesbian Muslim.

If only those opposing would join the discussion, they would find that Manji's views on Islamic tenets are not that deep and subject to debate because of her unimpressive and unreliable scholarship. For example, she is much different from and not of the caliber of Yusuf al-Qaradhawi, whose quality of writings and depth of work are internationally recognized by friends and foes.

Amid the country's growing fanaticism, religious tolerance marked by one's willingness to tolerate practices, persons or beliefs on religious grounds is the key to reshaping peaceful and blessed Indonesia.

Small steps are worth emphasizing in an effort to build tolerant Indonesian Muslims and reconcile liberal and fundamental Muslims in this country.

15 Sirozi, Muhammad, "The Intellectual Roots of Islamic Radicalism in Indonesia: Ja 'far Umar Thalib of Laskar Jihad (Jihad Fighters) and His Educational Background....., h. 81-120
First, reconciliation needs strengthening. Any talks with the warring parties should be seen as a continuous improvement process since there is no such thing as an overnight success. Religious violence is not just putting the victims as speechless hermits.

The Liberal Islam Network (JIL), for example, must be actively involved in deciding a common platform in a healthy and equal relationship together with militant Muslims such as HTI, MMI and FPI. While concealing latent conflicts to protect the privileges of majority groups would poison the atmosphere of the dialog, sharpening the conflict is believed to escalate confidence crisis over reconciliation efforts.

Attempts to overcome religious violence should touch upon deep structure of the conflict rather than its mere surface. One should know the extent of repeated religious tension. Does the tension have anything to do with uncompromising faith or is it simply a matter of miscommunication? Is it detrimental to the basic tenets of religion? Incomprehensive understanding of the tension would not bring about right solutions for the deep-seated religious problem. Failure to plan is a plan for failure.

Second, esoteric religion paves the way for fostering non-violent approaches to the conflict. Sufism makes believers distance themselves from various conflicts. They tend to accommodate and embrace differences. Esoteric religion assumes that conflict, violence and contradiction ruin the mood and damage purification of the soul (tazkiyah alnafs).

Indonesian Muslims may learn from the Khudai Khidmatgar (Servants of God) Movement in India, the Imam of Sarh in Chad, the Muslim Peace Fellowship (Ansâr asSalâm), and a dynamic international orator, Zakir Naik. The groups and the man have set important precedents for esoteric traditions to be instrumental in creating sociopolitical and 
religious reconciliation. As for Sunnis-Shiites or liberal-fundamental Muslims, their cooperation in developing Sufism may prevent ruptures on account of their strong emphasis on fiqhism.

Third, the ruling elites and security apparatus must stand in the front and provide exemplary behavior. It is unworthy that they are busy bringing down other quarters instead of backing up their fellows and enforce the law equally to serve the rank and file. It is high time that the elites and security apparatus sign a joint agreement establishing and transforming positive values into all elements of national power.

The stronger commitment the elites and police officers have to develop the nation and defend the oppressed, the higher the zest the people have to hold on to their leaders. People are in dire need of concrete evidence and are fed up with imaginary politics. People in conflict-stricken areas do not care about political interests. They long for honest amity on one side and want their leaders to forego their own vested interests and instead work for the good of the country on the other.

Fourth, religious conflict requires cultural resolution. For this purpose, the government does not have to go abroad seeking comparison. They could go to and learn from Yogyakarta despite public resistance to Manji at UGM in the city ${ }^{16}$.

Yogyakarta is not only famous for its reputation as the country's most livable and favorite student city. It also represents tolerance. Not simply does the city become a meeting point of diverse ethnic groups, races, or nationals. Rather, Yogyakarta still plays a major role as the center and the guardian of Javanese arts and culture, where traditions are preserved here.

${ }^{16}$ Lim, Merlyna, "Islamic Radicalism and AntiAmericanism in Indonesia: The Role of The Internet", Policy Studies, 18, 2005, p. 23
I believe the attack on Irshad Manji in Yogyakarta would not destroy its image as a city of tolerance so long as its residents adhere to their extraordinary center of excellence and culture. It only through those two things Yogyakarta can prevent extremely religious groups from growing. Religious tension hardly occurs owing to the city's welcoming and open people as well as charismatic Sultan Hamengkubuwono X's role in maintaining peace.

Despite its unsettled administrative status, Yogyakarta is able to craft firm genuine engagement of diversities within bonds of civility. This republic should learn from Yogyakarta to shape and reshape tolerant people so as to preclude the increase in religious hostility ${ }^{17}$.

\section{Terrorism and Cyber Religion}

Internet and social media (hereafter, "socmed") have grown exponentially to the point that speaking about the impact of them upon human lives is probably a cliché. Among two hundred and fifty million Indonesians, there are around eighty-two million of them online 18 . Indonesian youngsters occupied $82.8 \%$-the largest portion- of the Indonesian internet users 19 . The penetration of mobile device is even more impressive as it exceeds Indonesia's population. However, the sosmed has finally been missused by the people, especiallt to the activities related to radicalism ${ }^{20}$.

The government's decision to shut down at least 11 radical websites and several

${ }^{17}$ Lim, Merlyna, "Islamic Radicalism and AntiAmericanism in Indonesia: The Role of The Internet....., p. 1.

18 Team Kominfo. Pengguna Internet di Indonesia capai 82 juta, http//www. Komimpfo.or.id. Accses 2014, May 8.

${ }^{19}$ Fealy, Greg, "Islamic Radicalism in Indonesia: The Faltering Revival......, p. 12

20 Team APJII \& Puskakom UI, Profil Pengguna Internet Indonesia 2014 (Jakarta: Asosiasi Penguna Jasa Internet Indonesia (APJII) and Puskakom UI, 2015), p. 12 
social media accounts on Saturday after a deadly gun and bomb attack on last Thursday should be seen as an effort to block online radical contents from spreading even further. It is often time that those in entangled in diverse acts of terror have been greatly inspired by online sources taken from internet for free.

Many view the soaring online religious literacy as representing cyber religion. Thanks to its globally wider accessibility, unfortunately, cyber religion has been misused for spreading violent ideology. It paves the ground for strong act and thought of terror on behalf of religion ${ }^{21}$.

In Ghifarie, cyber religion discounts the importance of a living teacher. Comprehending religious doctrines without direct guidance of religious teachers and scholars is detrimental to the true messages. Those who learn religiosity and spirituality from books and cyberspaces in the absence of a guide are likely to go ashtray. Religious messages comprise multiple layers. Quranic verses, for example, could be read and interpreted from the perspectives of figh (jurisprudence), tashawnuf (spirituality) or falsafah (philosophy). Despite its diversity, Muslims would get into the true messages of the Holy Book so long as the experts are around $^{22}$.

Relying on internet instruments such as Google or Facebook for certain spiritual tenets frequently let people fall into shallow and artificial understanding. There is no room for an authentic spiritual experience within limitless cyberspace, while spirituality requires depth meaning and aura. The two thingsdepth meaning and aura-would be only found in real and physical body, touch, and

${ }^{21}$ Ghifarie, Iman Fauzi, "Teologi Hakimiyah: Benih Radikalisme Islam", Islam Realitas: Journal of Islamic \& Social Studies, 2.1, 2016, h. 10-33.

22 Azra, Azyumardi. "Bali and Southeast Asian Islam: debunking the myths." After Bali: The Threat of Terrorism in Southeast Asia, 2003, p. 39-57. encounter, not in the artificial world, like cyber space.

This is apparent in the case of the emergence of Indonesian young jihadists that recruited by some groups, including ISIS/ISIL, through socmed such as Facebook, as spotted by Noor Huda Ismail, an observer of radical Islamism in two interviews. The imageries of jihadists holding AK-47 in Facebook cover photos for instance, might induce the impression of gallantry, cool and dashing for other young jihadists. Those are converged with Islamic messages that give these youngsters religious meaning and passion, such as, "live a noble life or die as a martyr" (ish kariman aw mut shahidan). ${ }^{23}$

Being direct, real and physical, a teacher or guide plays a momentous role in transferring religious knowledge into one's heart. Religious knowledge is light and should be transferred from the heart, not from a book. The essence of religion is compassion, aiming to liberate instead of oppressing and teaching hatred. Marked by violence, terrorism bubbles to the surface since religious principles have been detached from their nature, that is to say compassion, for the dearth of teachers, guides and scholars.

In addition, cyber religion seems to be trapped into single interpretation and leave less room for dialogue and multiple interpretations. Many articles on the internet_online writings-are free verses, which are not always equipped with academic standards such as footnote and endnote. Uncritical people with high religious sense of curiosity turn out to be the subjects to the doctrinaire writings. Once swayed by those kinds of writings, one easily slips into blaming behavior and finds it hard to receive alternative way of thinking.

${ }^{23}$ Ismail, N. H., Jihad selfie: Searching for the Black Swan [Video Trailer]. (Melbourne: Western Publish, 2015), p. 32. 
In the aftermath of recent Semanggi shooting, some of my students link the terrorist acts to the masculinization of God. Driven by their linguistic and literary background, they reckon that religious radicalists in Indonesia are ignited by their erroneous assumptions in interpreting that God is a masculine entity. In Hayati, this masculinity is clearly denoted by the use of pronoun buwa (he) in Arabic which is a masculine third person singular. Hence, any attempts to neutralize God's gender will help contain the radicalism movement, suggesting a purely linguistic attempt ${ }^{24}$.

I see their critical points and appreciate them. What they miss, however, is that they close their eyes to the opposite standpoint. In an attempt to enrich their notion, I said that trying to equalize the attributes embedded to God with those to human kinds (male or female) is a misleading effort. Lay persons will not be tempted to think in this way, let alone Muslim radicalists who are ready to die (socalled jihad) to maintain what they think ideal and approved by God.

\section{Deradicalization Needs Critical Education}

It is through critical education which is able to root out terrorism from this region by degrees. While security approach is more to do with the surface structure, critical education is aimed at deconstructing basic tenets causing terrorism. It is through critical thinking that fluid nature and methods of terrorist organizations which are constantly adapting to law enforcement procedures and goals could be tamed.

Adopting Freire's concept on consciousness $^{25}$, terrorism and violence are inseparably bound to soaring native consciousness. Suicide bombers could be

24Hayati, M. A طاهرة العنف اللغوي في الميزان" . Iالشر عي، المشكلات والحلول." Islam Realitas: Journal of Islamic \& Social Studies, 2.1, 2016, h. 44-62.

${ }^{25}$ Freire, Paulo, Education for Critical Consciousness. (New York: A\&C Black, 2005), h. 20 categorized as having such a naïve consciousness. They usually do not have the ability to act and move. Rather they are steered by any particular ruling figures based on misleading concepts of religion. Authority belongs to leaders, such as interpreting holy texts. Allowing leaders to exercise control over them is a part of holy fidelity and sincere dedication.

As long as interpreting authority still belongs to particular persons, it will be likely to force others, namely subordinate people, to do the brutality. Many cannot think clearly since loyalty and absence of dialogue stand hand by hand. Not surprisingly, someone with naïve consciousness tends to do much damage. Suicide attack on places of worship, like church and mosque, could be seen as damaging the earth and human beings at such an unprecedented rate.

Silberman mentioned five possible ways that fundamentalism could lead to violence. ${ }^{26}$ The first is related to certain values that religion advocates that are, in a sense, prejudicial. This is evident from research predicting prejudice using fundamentalism. The second is attributed to the so-called religion's 'authority' to justify immoral actions in the name of God. The third way is through de-sanctification. Fundamentalists often ask others to respect their belief and not desanctify it by, for example, not criticizing it, even though they themselves often do not respect others' beliefs. fourth deals with fundamentalism in relation to cognitive simplicity. Desire for simplicity impairs individuals' ability to take different perspectives and may lead to attribution bias or belief perseverance. All of these pave the way to violence or intolerance. Finally, fundamentalism can lead to violence through proselytization. In Indonesian history,

26 Muluk, Hamdi and Dhyah Madya Ruth, "Terrorism and Psychology", Asian Journal of Social Psychology. 2, 2, 2012, p.102-103 
proselytism is a sensitive issue, particularly in Islam-Christian relations, and has led to attacks against the houses of worship of other religions.

The critical education might play a significant role in extirpating terrorism from earlier times. The critical education is a basically adult education full of love and affection. One is urged to think and be conscious that he or she is a part of earth within a macro-cosmos calling for human preservation. Furthermore, the critical education asserts that das Sein is not a must. By the time distortion and abuse appear, one is required to remedy the situation.

A myriad of terror acts against places of worship is not never-ending vicious circle. Rather it constitutes a distorted human civilization exerting stress upon one-sided coercion. Any efforts to get things right and done greatly serve to foster one's freedom and self-reliance. Only free and independent person, as representing Freire's core humanization, than might prevent human beings' deviant attitude from going worse.

In response to increasing religious extremism, the critical education must consider a dialogical approach, the end of cult personality, and the strengthening of philosophy. The dialogical approach is a key to creating independent and free persons. Through dialogue, one learns to foster a greater balance between freedom and openness on one side as well as responsibility and control on the other. People' awareness of dialogue causes them to turn from themselves and learn to listen to others' views and needs ${ }^{27}$.

Religious extremism frequently comes to sight since people, particularly younger people, too much bear down on normative rightwrong yardsticks instead of contextual preciseimprecise values based on monological style.

27 Hamilton-Hart, Natasha, "Terrorism in Southeast Asia: Expert Analysis, Myopia And Fantasy", The Pacific Review 18.3, 2005, p. 303-325.
The dialogical religious experience does not simply make people tolerate differences of opinion or practices of others, but also encourages them to respect others, characterized by the concept of "to agree to disagree". There will be no extremism as everybody reaches a common platform and respects different thoughts.

Preventing cult personality is equally necessary. There seems to be a tendency that Indonesia's religious extremism is marked by a rise in lone jihadists. The so-called lone jihadists rely upon individuals for interpreting Islamic messages conveyed by fundamentalist Muslim scholars. They absorbed the teaching from books and the internet without in a poorly logical and dialectical manner.

Leaders of Nahdlatul Ulama and Muhammadiyah representing mainstream Muslim organizations need to take a role in countering extreme doctrines by joining antiterror campaign, reiterating they stand by Indonesia's constitutional protection of religious freedom, and assuring the public that the state will take all necessary steps to guarantee it for all Indonesians regardless of their faith. Cult personality could only stop as anti-terror agenda involves Muslim leaders and all segments of society ${ }^{28}$.

Young Muslims need to be provided with art, literature, and philosophy. Islamic boarding school students, for instance, ought to be exposed to art and literature to see a world beyond the black and white. Art and literature can soften human's soul and mind. In terms of crotical thinking, teaching philosophy might change militant people after failed effort to talk to them hundreds of time.

Philosophy makes Muslims more curious about their doctrines in a critical manner without having the fear of eliminating authentic doctrines. Bolstered by dialogical

28 Hamilton-Hart, Natasha, "Terrorism in Southeast Asia: Expert Analysis, Myopia And Fantasy......, p. 303-325. 
method, philosophy becomes the key to shielding young Muslims from falling under the influence of the extreme Muslim figures and narrowing the field for potential radicals ${ }^{29}$.

\section{Conclusion}

Various terrorist attacks which have taken place across in some parts of Indonesia require various approaches as the resolution: First, the ambassadors of tolerance who are not only knowledgeable and transparent figures but also activists who devote their life to reviving the lost and scattered wisdomtolerance, brotherhood and mutual cooperation. Second, reconciling liberal and fundamental muslims. We can learn from Yogyakarta which represents tolerance. It is not simply become a meeting point city of diverse ethnic groups, races, or nationals, rather, Yogyakarta still plays a major role as the center and the guardian of Javanese arts and culture, where traditions are preserved here. Third, the government's decision to shut down at least 11 radical websites and several social media accounts should be seen as an effort to block online radical contents from spreading even further. It is often time that those in entangled in diverse acts of terror have been greatly inspired by online sources taken from internet for free. At last, through critical education which is able to root out terrorism from this region by degrees: critical education is aimed at deconstructing basic tenets causing terrorism

\section{References}

\section{Text Books}

Team APJII \& Puskakom UI, Profil Pengguna Internet Indonesia 2014 (Jakarta: Asosiasi Penguna Jasa Internet Indonesia (APJII) and Puskakom UI, 2015).

${ }^{29}$ Ritonga, A. Rahman, "Memaknai Terminologi Jihad dalam al-Quran dan Hadis", Islam Realitas: Journal of Islamic \& Social Studies, 2.1, 2016, h. 92-104.
Freire, Paulo, Education for Critical Consciousness. (New York: A\&C Black, 2005).

Ismail, N. H., Jihad selfie: Searching for the Black Swan [Video Trailer]. (Melbourne: Western Publish, 2015).

Team Kominfo. Pengguna Internet di Indonesia capai 82 juta, http//www. Komimpfo.or.id. Accses 2014, May 8.

\section{Journals}

Abbas, Afifi Fauzi, "Aspek Aspek Kemanusiaan dalam Terorisme Berdasarkan Kajian Fikih", Islam Realitas: Journal of Islamic \& Social Studies, 2.1, 2016.

Azra, Azyumardi, "Bali and Southeast Asian Islam: Debunking the Myths", After Bali: The Threat of Terrorism in Southeast Asia, 2003.

C, Ummah, Sun, "Akar Radikalisme Islam di Indonesia", Humanika, 12.1, 2012.

Fealy, Greg, "Islamic Radicalism in Indonesia: The Faltering Revival?", Southeast Asian Affairs, 2004.

Ghifarie, Iman Fauzi, "Teologi Hakimiyah: Benih Radikalisme Islam", Islam Realitas: Journal of Islamic \&o Social Studies, 2.1, 2016

Hamilton-Hart, Natasha, "Terrorism in Southeast Asia: Expert Analysis, Myopia And Fantasy", The Pacific Review, 18.3, 2005.

Hayati, M. A تاهرة العنف اللغوي في الميزان" . Islam Realitas: Journal of Islamic \& Social Studies, 2.1, 2016

Hendry, Eka, "Pengarus Utamaan Pendidikan Damai (Peaceful Education) dalam Pendidikan Agama Islam (Solusi Alternatif Upaya Deradikalisasi Pandangan Agama)", At-Turats, 9.1, 2015.

Lim, Merlyna, "Islamic Radicalism and AntiAmericanism in Indonesia: The Role of The Internet", Policy Studies, 18, 2005.

Millie, Julian, and Linda Hindasah, "Regional Aspects of the Indonesian Ulama 
Council's Ideological Turn", The Asia

Pacific Journal of Anthropology, 16.3, 2015.

Muluk, Hamdi and Dhyah Madya Ruth, "Terrorism and Psychology", Asian Journal of Social Psychology, 2, 2, 2012.

Muqoyyidin, Andik Wahyun, "Membangun Kesadaran Inklusif Multikultural untuk Deradikalisasi Pendidikan Islam", Jurnal Pendidikan Islam , 2.1, 2013.

Ritonga, A. Rahman, "Memaknai Terminologi Jihad dalam al-Qur'an dan Hadis", Islam Realitas: Journal of Islamic \& Social Studies, 2.1, 2016.

Rokhmad, Abu, "Radikalisme Islam dan Upaya Deradikalisasi Paham Radikal", Walisongo: Jurnal Penelitian Sosial Keagamaan, 20.1, 2012.

Razi, Syafwan, "Dari Islam Radikal ke Islam Pluralis Genealogi Gerakan Paderi dan Pengaruhnya terhadap Islam Pluralis di Perbatasan Minangkabau", Masyarakat Indonesia, 41.1, 2016

Saradin, Fauzi, "Strategi Penanggulangan Komunitas Gafatar dalam Rangka Mewujudkan Keamanan dalam Negeri Yang Kondusif (Studi Kasus Di Kabupaten Mempawah)", Jurnal Nestor Magister Hukum, 4.4, 2016.

Sirozi, Muhammad, "The Intellectual Roots of Islamic Radicalism in Indonesia: Ja'far Umar Thalib of Laskar Jihad (Jihad Fighters) and His Educational Background", The Muslim World, 95.1, 2005.

Van Bruinessen, Martin, "Genealogies of Islamic Radicalism in Post-Suharto Indonesia", South East Asia Research, 10.2, 2002.

Zora, A., Sukabdi, "Terrorism in Indonesia: A Review on Rehabilitation and Deradicalization" JTR, Vol. 6, Issue. 2, 2015 